\title{
Role of Consent in Arbitration between States and Nationals of Other Countries before the International Center for the Settlement of Investment Disputes
}

\author{
Jalal Aead Shwarah ${ }^{1}$ \\ ${ }^{1}$ World Islamic Sciences and Education University, Jordan \\ Correspondence: Jalal Aead Shwarah, World Islamic Sciences and Education University, Jordan. E-mail: \\ jalal_lawyer@yahoo.com
}

Received: May 18, 2019

Accepted: July 25, 2019

Online Published: August 2, 2019

doi:10.5539/ilr.v8n1p144

URL: https://doi.org/10.5539/ilr.v8n1p144

\begin{abstract}
This research aims at addressing important issues surrounding settling the investment disputes between the states and the national of other states when they decide resort to the international center for settling the disputes.

Specifically, this research focused on role of consent in arbitration, and degree to which the center commitment to Washington convention especially to article (25) from the convention. To avoid any possible contradictions in the process settling the dispute which will have negative impacts on the parties.

To achieve the objectives of this research, the researcher depended on the descriptive research method through in -depth review of a set of articles dissertations, websites and books.

Results of this research have implications to the parties involved in organizing the arbitration procedures according to principles of Washington convention underlying the arbitration centers provisions.
\end{abstract}

Keywords: arbitration, consent, ICSID, investment dispute settlement, jurisdiction, Washington convention

\section{Introduction}

The reasons that lead Contracting Parties in the investment contracts to accept arbitration before the Center as a means of resolving existing or potential disputes range from the jurisdictional immunity enjoyed by the host countries to investment, where they cannot be sued before a national jurisdiction of another State, In respect of disputes to which the State or one of organs is a party; the risk of the bias of the national judiciary against the interests of the contracted State shall be avoided by 1- virtue of its exclusive jurisdiction and a more impartial judiciary ${ }^{1}$. Hence, the investor concerned with the State is keen to include the investment contract in the arbitration clause, which refers to arbitration of the International Center for the Settlement of Investment Disputes between States and nationals of other countries. At the same time while the latter is a means of encouraging investment for developing the countries. If the objective of the Center is to provide judicial guarantees foreign investors in order to encourage investment in the developing the countries and to remove the jurisdiction of national courts for the consideration of disputes arising out of any political risk or action by the State against them ${ }^{2}$; However, resort to the Center is service is based on the agreement of the parties.

This is confirmed by the fact that the founders of the Washington Convention for the Settlement of Investment Disputes stressed the need for investment contracts to include this principle or to agree upon the center arbitration after the break out of conflict ${ }^{3}$. Does the arbitration court comply with the agreement nature of the Washington Convention in order to accept the Center's jurisdiction? To answer this question, the joint consent of the parties to resort to arbitration of the Center in the form of an arbitration agreement (first topic) will be discussed, and then the Center will accept its specialization even in the absence of an arbitration agreement and the extent of influence on the contractual nature of arbitration. 2

\footnotetext{
${ }^{1}$ Al-mesbahi, A. (2013). Role of the judiciary in Appling and investment the international agreement in the investment disputes, Work paper, fourth conference of heads of supreme courts in the Arab countries held in Qatar from 24-26 September.

${ }^{2}$ Abdurrahman, A. (1991). Economic development contracts in the Special International Law, Al-Nasr library, Cairo University, p 7.

${ }^{3}$ Alasad, B (2006). Investment Contract in the Special International Relations, Al-Halabi law publications. First Edition, Beirut, p. 328.
} 


\section{Arbitration Agreement Devotes to the Contractual Principle of Arbitration}

The first thing included in Washington Convention, is the jurisdiction of the Center, which is based on the consent of the parties to submit the dispute to it; it is found that the State not only based that the ratifies the Convention to determine jurisdiction, but must subsequently consent to the presentation of the dispute and in an explicit form ${ }^{4}$, Is subject to the will of the parties even for the member states. The elements of the dispute should be available in accordance with the terms of the agreement, represented by its subject and its persons (first demand), which are considered provisions for the completion of the conciliation pillar.

The role of the will depends not only on determining the centers specification, but also extended to include participation in the freely formation of the arbitral tribunal, which considers the dispute in accordance with the principle of the will, which gives the conflicting parties the choice to select the law applicable to the subject, (Second requirement), although the Convention was keen to regulate the conduct of the dispute self-sufficiency in the case the absence of agreement between the parties.

\subsection{Determining the Competence of the Center according to the Will}

A jurisdiction of the arbitral tribunal of the Center for the consideration of the dispute requires the consent of the State in the investment contract ratified with the foreign investor ${ }^{5}$, in the form of an arbitration agreement to resolve a potential dispute, or when the dispute has been agreed to resort to the Center in the form of an independent party. The Convention also required the determination of the competence of the Center in two provisions; (One party is a Contracting State (a public party), a national of another Contracting State (a private party), the second requirement is that the dispute is legal; this entails the exclusion of the political dispute related to the investment; its specialty is purely commercial disputes (second branch).

\subsubsection{The Consent of the Parties upon Dispute Resolution before the Center}

Article 25/1 of Washington Convention provides that the mutual provision of the parties to refer the dispute to the Center is a necessary and essential condition of the Center's jurisdiction, which means that consensual consent is required in accordance with the contract; consent may be obtained before or after the break out of the dispute. If the investment contract contains an arbitration clause as a means of resolving disputes that may arise in the future between the contractors, it is expressed in this case by the arbitration clause or by an agreement independent of the original contract after an actual dispute has been settle to resolve the existing dispute known as, Arbitration ${ }^{6}$.

It should be noted from the above that the Convention did not use the terms condition and arbitration condition, but that can be concluded indirectly in order to demonstrate to the parties together, through the words "approve" in article 25/1 above. The arbitration shall be based on the satisfaction of the parties, whether prior to the dispute (s) or later (a partnership), although the agreement combines the two terms in one sense, and this satisfaction is the source of the compulsory force of the arbitration contract. . According to the contractual theory of arbitration.

Concerning the writing of the arbitration agreement, article 25/1 of the Washington Convention included this in a clear way that the mere orally declaration by either party or both about their intention to resort to the Center Cannot be considered as conciliatory within the meaning of the said article, In writing form ${ }^{7}$, noting that the Convention did not specify a specific form of writing, and left the field open to facilitate the conditions of international trade ${ }^{8}$, and liberating it from the restrictions of commensurate with the specificity of arbitration.

\subsubsection{Personal and Objective Competence of the Center}

The status of the parties is the most important peculiarity of arbitration at the Center because it includes the right of private law persons to be parties to the dispute; In arbitration, one of which is a State ${ }^{9}$, contrary to the practice that States only intervene in litigation, the parties to which are international persons or one of their legal persons

\footnotetext{
${ }^{4}$ Mohamadin, J. (1995). Arbitration under the international center umbrella for settling the Investment disputes.Al-dar Al-jamiya for publication and distribution, p.28.

${ }_{5}^{5}$ Al-hosani, W. (2010). The Arbitration Specialty for the International Center for Settling the Investment Disputes. ${ }^{\text {st }}$ edition,Dar al-Nada al-Arabia, Cairo, p 30 .

${ }^{6}$ Boalqararah, Z. (2011). Foreign Investment Dispute in the Algeria legislation, A Note Submitted for the Master Degree, Faculty of law and political science, p. 98 .

${ }^{7}$ Al-jondi, H. (2005). The legal system for settling the Foreign Investment Dispute in light of Washington Agreement signed year 1995, Dar Al-nahda, Cairo, p. 51.

${ }^{8}$ Al-jazi, O. (2014).Specialty of the Arbitration Board of the International Center Investment Disputes, $1^{\text {st }}$ Ed, law publications, Lebanon, p. 19.

${ }^{9}$ Governmental Contracts, (2004). United Nations Conference for Trade and Development UNCTAD,

Series of UNCTAD studies regarding the international investment agreement, United Nations, P. 12.
} 
if the State so acknowledges. In order for the dispute to enter the jurisdiction of the Center, one of the parties shall be a Contracting State and the other Party shall be a national of another Contracting State, whether natural or juridical. Consequently, disputes between governments or between the parties concerned shall not be within the competence of the Center ${ }^{10}$.

The subject matter of the dispute is any dispute of a legal nature directly related to an existing investment between the foreign investor and the host State ${ }^{11}$, which indicates that disputes of a purely political and commercial nature are excluded from its competence. This is insufficient, because the dispute will arise directly from the investment contract ${ }^{12}$.

\subsection{The Role of the Will in Organizing the Procedures}

The arbitration of the Center is based on the parties, agreement which is the essence and the basis of the entire system of arbitration, It derives its existence and power from the principle of "power of will", According to the proponents of this principle, The formation of the arbitral tribunal, the selection of the law applicable to the dispute so that the judgment of the arbitral tribunal is based on a valid agreement, and this will have an effect on the effectiveness of the arbitral award ${ }^{13}$. To what extent does that correspond to the provisions of the Washington Convention establishing the Center?

The Washington is Convention did not neglect the principle "power of the will" to regulate arbitration proceedings, but rather it embodied it in other aspects. It gave the parties the absolute freedom to form an arbitral tribunal in accordance with the provisions of the Convention, In order to settle the dispute under the concluded arbitration contract.

\subsubsection{Composition of the Arbitral Tribunal}

The principle of consensualization allows the parties to the dispute to contribute positively to the composition of the arbitration court ${ }^{14}$; each party to the dispute appoints an arbitrator from the pre-established list of arbitrators.

But the question that arises here is: How arbitration board list of (pre-prepared) arbitrators formed to guide the parties when they form the arbitral tribunal, even though they are not bound by it, as long as it allowed them to choose from outside the list under certain conditions?

In accordance with the flexibility of the Convention, and until the arbitration proceeding begins, the parties shall elect the members of the arbitration board to deal with the dispute from a list of arbitrators ${ }^{15}$, provided that the arbitrator agrees to be named in the list ${ }^{16}$. The arbitrator, unlike the judge, does not have to be a legal man only, but requires qualifications and specialization in the field of activity that is related to the subject matter of the dispute, and the control of its facts without being obliged to hire experts.

Regarding the appointment of appointees and the number of persons to be appointed, article 13 of the Convention has dealt with it as follow;

1) Each Contracting State may designate four persons for each list and shall not necessarily be from its nationals.

2) The President may designate 10 persons for each list and shall be nationals of different States for the same list. It is striking in this article that it granted the power to appoint arbitrators within their own list, to each of the Contracting State, including the State of the Investor, without the investor himself. The Convention gives the parties to the dispute a wide freedom to choose their arbitrators; they may thus choose the number of arbitrators

\footnotetext{
${ }^{10}$ Ziade, N, (1998). ICSID and Arab Countries, article News from ICSID, Vol.5, No.2, Summer, p 6.

${ }^{11}$ Reuter, $\mathrm{P},(1969)$. reflexion sur la competence de center cree par la convention pour le reglement des differends relatifs aux investissements entre Etat et ressortissants d'autresetats in 'investissements etrangers et arbitrage entre etats et personnes privees', Pedon, Paris, p16.

${ }^{12}$ Article1/25 in the first part fit,, specialty of the center extends to disputes with legal nature which break out between contracted state and nationals of other contracted state which directly connected with one of the investors .

${ }^{13}$ Al-basheer, A. (2009). Arbitration Specification in front of the International Center to settle the Investment disputes, A thesis for Graduate studies Deplume in the Special Law, Business law Branch, Faculty of legal sciences, Economic and Social Sciences university of Al-Hasan the first, kingdom of morocco,p.118.

${ }^{14}$ Mohamadeen, J, (1995). Arbitration under umbrella of the international center for settling the Investment Disputes, Dar Al-Jamia for Publication and Diploma Distribution, Cairo, p.55.

${ }^{15}$ Balharsh, s, (2006). International Center for Settling the Disputes Related to the Investment and the used procedures in front of it, An intervention in the international forum about the commercial Arbitration in Algeria between legal and arbitration practices, Bjaya university, faculty of law,p.291.

${ }^{16}$ Qabaili, T, (2010). Consent over the Arbitration of the International Center for Settling the Investment Disputes, from the bilateral agreement to individual, The Academic Journal for the Legal Research, Abdarhman Mira University, Bjaya,p.405.
} 
they deem appropriate to form the body, provided that should be odd number 3 (article $27.2(\mathrm{a}))^{17}$.

It should be noted that most of the cases before the Center have been the formation of courts from one or three arbitrators ${ }^{18}$. In line with the flexibility of the Convention, Article 40.2 authorizes Parties to select arbitrators from outside the pre-prepared lists, provided that the same conditions and qualifications, required by the mentioned arbitration in the list are met $^{19}$.

\subsubsection{Role of Will in the Choice of the Applicable Law to the Conflict}

The Washington's Convention gave the parties a wide space of freedom to determine the law applicable to disputes arising from the investment relationship between them ${ }^{20}$. The parties have complete independence in the choice of the applicable law adopted by the arbitral tribunal to consider the dispute before it, in the Arbitration procedures on the arbitration board dispute topic.

With regard to the applicable law to the proceedings of the dispute, the Convention enjoys self-entity in determining the rules of procedure, and only adopts them if the parties agree upon other procedures, as provided for in article 44 thereof; "However, the administration of all arbitration procedure shall be in accordance with the provisions of the Convention as well as the Arbitration Rules before the Center, unless otherwise agreed upon by the parties ...".

The Court of Arbitration shall first comply with the procedures provided for in the Convention or the Regulations of the Center. If no provision is made to deal with a particular procedure, the procedure agreed upon by the parties shall be in force. In the absence of the agreement, the arbitrator shall choose the appropriate procedures $^{21}$, The UNCITRAL Model Law on International Commercial Arbitration (UNCITRAL) has adopted this solution in article ${ }^{22}$.

Although the rules of this Convention are applicable to arbitration proceedings in accordance with the provisions of article 44, they may be breached if the parties agree upon applying another law. The Convention applies in the event that the parties do not agree upon the application of a particular law, let alone that the procedures followed by the Center Concern a lot about flexibility; the parties to the conflict are not obliged to abide by many of the rules imposed by the Convention, which they can dispense with and agree on what violates them, including the arbitration procedures ${ }^{23}$.

As to the choice of law applicable to the subject matter of the dispute, article $42 / 1$ of the Convention states in its first paragraph that "the court shall decide the dispute in accordance with the legal rules recognized by the parties to the dispute." This statement clearly shows us the freedom of the parties to choose the law governing the subject matter of the dispute, and this is only an application of principle of consensual basis on which the arbitration agreement was based, upon expanded or extended to be a source of the rules governing the arbitration, Or during proceedings before the Court ${ }^{24}$.

Thus, the Court of Arbitration is prevented from resort to the application of another legal system in the case of presence of an agreement upon a law ${ }^{25}$, in strict accordance with the principle of the absolute will, 2 which mean that the parties can choose the law of a particular State or general international law ${ }^{26}$. They may also choose legal rules from several systems or common legal rules from the national law and general international law. This is understood by the term "legal rules" instead of "the law" in article 44, which states that the agreement of the parties is not restricted to a particular legal regime, They have the freedom to choose more than one law or even to divide the contract and subject it to more than one law.

\footnotetext{
${ }^{17}$ Rubino - Sammartano, M. (2014), International Arbitration Law and Practice, Third Edition, Juris Publishing, USA,P 410.

${ }^{18}$ See the law suit table at the centre's site, www.wordbank.org/icsid/cases (Last visible 18/5/2019).

${ }^{19}$ Qabaili,T,(2007),(Ibid),p.405.

${ }^{20}$ Khaled, H, (2007). The Essence of the International Contract, A Comparative Legal and juridical study, Alexandria,Al-ma'aref establishment, p100.

${ }^{21}$ Lew, J. (1987), Contemporary problems in International Arbitration, Springer Science and Business Media Dordrecht, p.305.

${ }^{22}$ Considering the provision of law, the two parties have the agreement freedom over the procedures that the arbitration body should follow during the arbitration proceedings, If there is no agreement, the arbitration body can proceed with the arbitration as it sees relevant.

${ }^{23}$ Rubino - Sammartano, M. (2014), International Arbitration Law and Practice, Third Edition, Juris Publishing, USA, P 410.

${ }^{24}$ Al-jom'a, Kh. (1998), International Center for settling the Investment Disputes as away to solve the Direct Investment Disputes, journal of law, Kuwait university, no.3,p.266.

${ }^{25}$ Al-samer'ai, D. (2006). Foreign investment, Barriers and legal Guarantees. Arab unity studies center, Lebanon, p.332.

${ }^{26}$ Al-jom'a, Kh, p.277 (Ibid)
} 


\section{Decline in the Will Role in the Arbitration}

Although the arbitration as mentioned above is based on the will of the parties, it is interesting to note that the practice of the Center has proved that there is a different approach to the previous one, which serves to expand the interpretation of article 25/1, whereby the Center accepts its jurisdiction even without agreement between the parties in the form as required by The provisions of the Washington Convention ${ }^{27}$. The arbitration courts of the International Center for the Determination of its Competence were satisfied with the existence of a legislative text referring To arbitration of the Center, whether in the domestic investment law of the host State or in a bilateral or multilateral agreement concerning the protection and promotion of investment (first requirement, if the foreign investor resorts to the request arbitration in front of the center.

The acceptance of arbitration without an agreement creates a kind of imbalance between the parties to the agreement to resort to Arbitration Center, which affects the principle of the power of will which is the contractual base (second demand).

\subsection{Justification for Acceptance of Arbitration Justifications for Accepting the Arbitration without the Parties' Agreement}

The host State may gives its consent to the competence of ICSID, the International Center for Settlement of Investment Disputes Through a text contained in its internal law on investment, expressing satisfaction with the center competence. Such consent shall be supplemented by the investor's subsequent acceptance (first branch) or in the convention law in two forms; either by bilateral or multilateral agreement (sec.2).

\subsubsection{Based on the Internal Investment Law of the State}

The investment law of the host country may include a text indicating at the acceptance of arbitration at the Center as one of the possible methods to settle the investment disputes with foreign investors, but this does not preclude the State from resorting to other means provided for in domestic legislation ${ }^{28}$, Investments and granting investors various guarantees through the provisions of Article 43 of the Investment Law "settle investment disputes between the government agencies and the investor amicably within a maximum period of six months, otherwise the parties to the dispute have the right to resort to the Jordanian courts or settle disputes under the Jordanian law or resort to alternative means to resolve disputes by the two parties agreement. "

We conclude from this text that any dispute that may arise between Jordan and a foreign investor may be settled amicably within a period of six months, or if the dispute is not resolved in a friendly manner, it can be settled by the competent judicial authorities, The belief that the internal judiciary is competent, but this belief quickly disappears when continue reading the text, which gives the parties the right to choose arbitration as a method of settlement, if Jordan as a host country party to a bilateral or multilateral agreement, Since the Arbitration center is the most important option available to the investor to claim his rights against the Jordanian state, it becomes the main instrument for resolving the contractual disputes between Jordan and the foreign investor.

The possibility of achieving satisfaction as required for the status of the Center as mentioned above led to the break out of the first case in which the Center accepted an arbitration case by a private person against a State based on national legislation of this State, referring to arbitration ${ }^{29}$, which Egypt was a party in it.

The case is summarized in an investment agreement concluded between the Government of Egypt and a South Pacific Company (spp) with the aim to establishing two tourist complexes. IegothCompany shares this agreement with the approval of the Government of Egypt ${ }^{30}$. However, following a dispute over an action taken by Egypt, after the dispute center that followed the attack on the project; it represents a real threat to the site as civilization, history and culture ${ }^{31}$. Subsequently, company (spp) initiated the arbitration procedure with the Center, with the aim to obliged the Republic of Egypt to pay compensation, after the cancellation of the project, based on text Article 18 of the Investment Law, which came in; "Investment disputes related to the implementation of the provisions of this law shall be settled in the manner agreed upon with the investor or

\footnotetext{
${ }^{27}$ Mohamadeen, J, (2001), p.20 (Ibid).

${ }^{28}$ Al-qasabi, I. (1998), Arbitration specialty in the Investment Disputes Field, Dar Al-nahda Al-Arabiya, Cairo, p.78.

${ }^{29}$ BEN HAMIDA, W. (2005), "Arbitrage etat investisseur face a un desordre procedural: la concurrence des procedures et les conflits de juridictions", Annuaire Francais de droit international, Paris, p566. GAILLARD, E, (1992) centre international pour le reglement des differends relatifs aux investissements cridi, chronique des entences, p217.

${ }^{30}$ Kojan, A. (2008), Arbitration in the investment Contracts Between the State and the Foreign Investor According to the International Center's Provisions for settling the investment Disputes in Washington, Zain law publications, Beirut,Lebanon, p.233.

${ }^{31}$ Yameenah, H, (2011), Consent to arbitration before the International Center for Settlement of Investment Disputes (ICSID), Master of Law, International Law of Cooperation, Mouloud Mameri University Tizi - Zer, p 74.
} 
within the framework of the agreements in force between the Arab Republic of Egypt and the Investor State or within the framework of the settlement of investment disputes between States and citizens of other countries to which Egypt has acceded under Law No. 90 For the year 1997 in the cases in which it applies "32.

The Court pointed out that the Convention did not require a special form of satisfaction that required the jurisdiction of the Center, unless it is in writing. However, the authors of the Convention assumed that the State could give its consent to arbitration at the Center ${ }^{33}$; Article 8 of the Egyptian Investment Law the Republic of Egypt explicit satisfaction in written to resort to Arbitration Center in accordance with Article 25/1.

Subsequently, the cases in which the domestic legislation of the host State was invoked took place. In addition to Egypt, there were Tunisia, Albania, Georgia and other States ${ }^{34}$. The acceptance of arbitration with the Center, based on internal legislation, which emptied arbitration of the voluntary nature of the Convention to resort to the center from its value, which is considered a violation of the fundamental principle, the principle of "the power of will".

\subsubsection{Based on the Host Countries' Convention Law}

Countries conclude a larger number of agreements these days, especially with the big powers, in order to benefit from their technologies and capital. These agreements aim to establish a comprehensive system of investment issues, including the settlement of disputes. These agreements may include provisions that allow resorting to Arbitration Center to settle disputes in order to avoid recourse to the internal jurisdiction of the host country. Bilateral and multilateral, although there was no item in the contract indicates at referring the dispute to the center, and considering that Jordan is one of the countries that has concluded many of these agreements, it has adopted the method of referral to the Center whenever it comes to settle disputes between Jordan and the foreign investor. Examples of these agreements include the following:

The agreement aimed at encouraging investment between Jordan and the United States of America, issued on 2/7/1977, where Jordan entered into bilateral investment agreements with 59 countries.

The judgment of 27/6/1990 in the dispute between AAPL and the Republic of Sri Lanka is the first ruling establishing the jurisdiction of the arbitral tribunal based on the existence of a provision in an investment agreement that refers to arbitration of status ${ }^{35}$.

States have sought to conclude bilateral agreements to protect, promote, and encourage investment, but not only have they concluded collective agreements at the regional scale, notably the North American Free Trade Agreement (ALENA) and the Energy Charter ${ }^{36}$.

Most of these agreements contain dispute settlement clauses, which often provide for one or more forms of arbitration, which are done within the framework of the International Center for Settlement of Investment Disputes (ICSID) either through arbitration under the Convention or under the ICC's additional facilitation rules. Under the terms of the Multilateral Investment Agreements (MIPs), recourse to arbitration of the Center without agreement in the traditional sense could be given to arbitration in general through the initiation of arbitral proceedings against the host State, where the State's consent to arbitration was achieved once the Convention had been ratified, The investor may, if he wishes file a claim, he achieves this by giving his written consent to submit the request for arbitration to the Center.

\subsection{Extent of the Influence of Arbitration without a Will on the Will}

The new approach adopted by the arbitral has proved to be unstable, as the result of this is a violation of a fundamental principle upon which arbitration is based on the principle of the will of authority. This has led to the imbalance in the bilateral consensual pillar (first branch). The State's approval of its investment law, or through the agreements that bind it with the investor's state. Accordingly, the investor relies on this approval to separate the request for referral to arbitration of the center, which led to decline in the role of will in arbitration (second branch).

\footnotetext{
${ }^{32}$ Qabaili, T. (2002), Arbitration of Investment Contracts Between States and Citizens of Other States in the light of the Washington Convention, PhD Thesis in Law, Faculty of Law, Mouloud Mameri University, Tizi - Ouzou, p.187.

${ }^{33}$ Hafdah H. (2006), Contracts Between States and Foreign Persons, University Publications House, Alexandria, Egypt, p.270.

${ }^{34} \mathrm{https}$ ://icsid.worldbank.org/apps/ICSIDWEB/cases/Pages/casedetail.aspx ?CaseNo=ARB/94/2, (Last visible 18/5/2019)

${ }^{35}$ https://icsid.worldbank.org/apps/ICSIDWEB/casedetail.aspx?CaseNo=ARB/94/2. (Last visible 18/5/2019 )

${ }^{36} \mathrm{https}$ ://bit.escwa.org.lb/Manual-on-Bilateral-Investment-Treaties.aspx.( Last visible 18/5/2019)
} 


\subsubsection{Imbalance of the Conciliation Pillar to Resort to the Arbitration}

The Washington Agreement did not include special conditions for consensual consent, and by reference to article 25/1, there was no requirement other than the requirement of writing. Accordingly, the Center based its jurisdiction on the basis of the internal investment law or the agreement with this route for a positive settlement directed to the foreign investors. By the investor acceptance the consummation of the agreement is complete. However, the arbitral tribunal proceeded in a different way. The investor can apply for arbitration individually, Or a bilateral or multilateral international agreement, and thus to lure the State or its institutions to arbitral tribunals contrary to their wishes or without their consent and to bring them into disputes they did not expect, while the State does not have the same right to establish procedures against the investor, which leads to the creation of an unbalanced position between the parties.

This advanced trend has pushed to a breach of the principle of equality between the parties to the arbitration application, as long as the arbitral proceedings depend on the initiative of the foreign investor and not on an agreement between them, while the State lacks the same right to initiate arbitral proceedings against the investor. Such arbitration as "compulsory international arbitration ${ }^{37 "}$, or "unilateral international arbitration. ${ }^{38}$ " In this regard, the State is individually bound to investors it does not know in advance, since it has no right to initiate arbitral proceedings against them, At the expense of the host State, and failing to achieve balance, between the interests of the parties to which the Convention was founded ${ }^{39}$.

\subsubsection{Change the Concept of Contract in Arbitration}

Non-conventional arbitration is determined in international investment relations as a preferred and necessary measure for the settlement of disputes between the State and the investor. It can be said that non-conventional arbitration is a mandatory procedure, in which the will of the host State is not directly available it is, mandatory requirement in arbitration before the Center, which is jurisdiction cannot be envisaged without Arbitration agreement ${ }^{40}$.

Therefore, the absence of a direct agreement between the individual parties - the State and the investor - must be interpreted as an acknowledgment of compulsory arbitration because the acceptance by the State of arbitration before the Center in investment legislation or in an international agreement with the Investor State concerns investment, Because the investor's will is not accompanied by the will of the state except when he begins to use arbitration procedures. However, accepting the center's jurisdiction based on this latter case is arbitrary in the state's right.

The question remains as to the procedure to be followed by the State in the case of the investor's failure to move the arbitration proceedings.

Because of this shift in arbitration at the Center, the requirement that the parties to the relationship concur with the jurisdiction of the arbitral tribunals should be taken into account when drafting the text of the first paragraph of article 25 of the Washington Convention; which is considered contrary to the basic principles of arbitration in accordance with this Convention ${ }^{41}$. After arbitration was initiated by agreement and then became mandatory after resorting to it, it cannot be withdrawn by unilateral will; it is reversed and became mandatory, by obliging the State to include in its domestic law or convention Badge to resort to the Center to resolve the dispute.

We can consider the non-convergence of the will of the parties to the relationship as the customary rule that supersedes the arbitration agreement in international investment contracts, especially since this new trend was decided by the ICSID from provisions, which leads us to say that the investor's initiation of arbitration proceedings with the Center And the acceptance by the latter of its competence, without such limitation being made directly from the arbitration agreement, even if this procedure is true in the field of arbitration; the satisfaction of the other client (ie the State) which is not equal to the satisfaction of the investor is contrary to the contractual basis of arbitration with the Center, which consider a change in the contractual the principles for arbitration, A change Principles of contractual arbitration.

\footnotetext{
${ }^{37} \mathrm{Al}$-asad, B. (2006), Investment contracts in the special international relations, $1^{\text {st }}$ Ed, Al-halabi law publications, Beriut, Lebanon, p.438.

${ }^{38}$ Al-majthoob, M. (2004). The general international law, Al-halabi law publications, Beriut, p.59.

${ }^{39}$ Al-as'ad, B. (2006), p.483 (Ibid).

${ }^{40}$ Article 1/25 from agreement of the investment disputes settlement under study... which states, under the provision the disputed parties agree in written to submit them to the center.

${ }^{41}$ Weldrabeh, s. (2012), About the arbitration legality through the individual international arbitration "the critical journal, The law and the political sciences, no.12, Moalood Mo'amary University, Tizi - Ouzou, p.187. p.107.
} 


\section{Conclusion}

This study revealed the basis of the arbitration agreement before the International Center for the Settlement of Investment Disputes (ICSID), as evidenced by the analysis and study of the text of Article (25) of the Washington Convention, which showed the freedom enjoyed by the parties involved in organizing arbitration proceedings. All stages of arbitration, from the arbitration agreement to the arbitration of the Center, which is already considered the basis for the arbitration of the Center on the one hand, and a comprehensive agreement on the other, in which the parties accept the principle of arbitration without any other settlement system, and choose the body that decides the dispute and determine the scope of its powers, Actions that are going on, the substantive rules that it adheres to.

However, if the contractual freedom recognized by the litigants before the Center in the field of investment is the general rule, there is a new approach taken by the arbitral tribunals of the Center, whereby it has departed from the general rule. This approach has led to the acceptance of arbitration even in the absence of an agreement between the parties based on internal investment legislation, or on the basis of bilateral or multilateral agreements of the host States, referring to arbitration of the Center.

This approach contract with the basic principles underlying the arbitration of the Center, which were based on the principle of consensual, because it led to the creation of an imbalanced position between the parties that tried to resort to it, and to a decline in the role of will in arbitration.

\section{References}

Abdurrahman, A. (1991). Economic development contracts in the Special International Law. Al-Nasr library, Cairo University.

Al-asad, B. (2006). Investment contracts in the special international relations(1st ed.). Al-halabi law publications, Beriut, Lebanon.

Al-basheer, A. (2009). Arbitration Specification in front of the International Center to settle the Investment disputes, A thesis for Graduate studies Deplume in the Special Law, Business law Branch, Faculty of legal sciences, Economic and Social Sciences university of Al-Hasan the first, kingdom of morocco.

Al-hosani, W. (2010). The Arbitration Specialty for the International Center for Settling the Investment Disputes(1st ed.). Dar al-Nada al-Arabia, Cairo.

Al-jazi, O. (2014). Specialty of the Arbitration Board of the International Center Investment Disputes (1st ed.). Law publications, Lebanon.

Al-jom'a, Kh. (1998). International Center for settling the Investment Disputes as away to solve the Direct Investment Disputes. Journal of Law, Kuwait University.

Al-jondi, H. (2005). The legal system for settling the Foreign Investment Dispute in light of Washington Agreement signed year 1995. Dar Al-nahda, Cairo.

Al-majthoob, M. (2004). The general international law. Al-halabi law publications, Beriut.

Al-mesbahi, A. (2013). Role of the judiciary in Appling and investment the international agreement in the investment disputes, Work paper, fourth conference of heads of supreme courts in the Arab countries held in Qatar from 24-26 September.

Al-qasabi, I. (1998). Arbitration specialty in the Investment Disputes Field. Dar Al-nahda Al-Arabiya, Cairo.

Al-samer'ai, D. (2006). Foreign investment, Barriers and legal Guarantees. Arab unity studies center, Lebanon.

Balharsh, S. (2006). International Center for Settling the Disputes Related to the Investment and the used procedures in front of it, An intervention in the international forum about the commercial Arbitration in Algeria between legal and arbitration practices. Bjaya university, faculty of law.

Ben Hamida, W. (2005). Arbitrage etat investisseur face a un desordre procedural: la concurrence des procedures et les conflits de juridictions. Annuaire Francais de droit international, Paris. https://doi.org/10.3406/afdi.2005.3898

Boalqararah, Z. (2011). Foreign Investment Dispute in the Algeria legislation, A Note Submitted for the Master Degree, Faculty of law and political science.

Gaillard, E. (1992). Centre international pour le reglement des differends relatifs aux investissements cridi, chronique des entences.

Governmental Contracts. (2004). United Nations Conference for Trade and Development UNCTAD, Series of 
UNCTAD studies regarding the international investment agreement, United Nations.

Hafdah, H. (2006).Contracts Between States and Foreign Persons. University Publications House, Alexandria, Egypt.

Khaled, H. (2007). The Essence of the International Contract, A Comparative Legal and juridical study. Alexandria, Al-ma'aref establishment.

Kojan, A. (2008). Arbitration in the investment Contracts Between the State and the Foreign Investor according to the International Center's Provisions for settling the investment Disputes in Washington. Zain law publications, Beirut, Lebanon.

Lew, J. (1987). Contemporary problems in International Arbitration, Springer Science and Business Media Dordrecht. https://doi.org/10.1007/978-94-017-1156-2

Mohamadeen, J. (1995). Arbitration under umbrella of the international center for settling the Investment Disputes. Dar Al-Jamia for Publication and Diploma Distribution, Cairo.

Mohamadin, J. (1995). Arbitration under the international center umbrella for settling the Investment disputes. Al-dar Al-jamiya for publication and distribution.

Qabaili, T. (2002). Arbitration of Investment Contracts Between States and Citizens of Other States in the light of the Washington Convention, PhD Thesis in Law, Faculty of Law, Mouloud Mameri University, Tizi - Ouzou.

Qabaili, T. (2010). Consent over the Arbitration of the International Center for Settling the Investment Disputes, from the bilateral agreement to individual. The Academic Journal for the Legal Research, Abdarhman Mira University, Bjaya.

Reuter, P. (1969). Reflexion sur la competence de center cree par la convention pour le reglement des differends relatifs aux investissements entre Etat et ressortissants d'autresetats in 'investissements etrangers et arbitrage entre etats et personnes privees'. Pedon, Paris.

Rubino - Sammartano, M. (2014). International Arbitration Law and Practice (3rd ed.). Juris Publishing, USA.

Weldrabeh, S. (2012). About the arbitration legality through the individual international arbitration "the critical journal, The law and the political sciences, no.12, Moalood Mo'amary University, Tizi - Ouzou.

Yameenah, H. (2011). Consent to arbitration before the International Center for Settlement of Investment Disputes (ICSID), Master of Law, International Law of Cooperation, Mouloud Mameri University Tizi - Zer.

Ziade, N. (1998). ICSID and Arab Countries, article News from ICSID, Vol.5, No.2, Summer.

\section{Copyrights}

Copyright for this articleis retained by the author(s), with first publication rights granted to the journal.

This is an open-access article distributed under the terms and conditions of the CreativeCommons Attribution license (http://creativecommons.org/licenses/by/4.0/). 